\title{
Pharmacognostic Study and Quantifiction of Active Component (Amarogentin) Of Swertia Chirayita by HPLC
}

\author{
Neetu Sharma, Ashish Sharma, Kumud Pant and Kapil Ghai
}

\begin{abstract}
The present study deals with comparative pharmacognostic parameters involving moisture content, ash values, extractive values and quantification of active component (Amarogentin) in whole plant of two different sites of Garhwal [Chakrata (CK) and Kaddukhal(KK)] in Uttarakhand of Swertia chirayita have been carried out. The quantification of amarogentin evaluated by HPLC, results indicate that Chakrata site has higher percentage of amarogentin than Kaddukhal site. Adulteration and substitution of medicinal plants can be prohibited by standardization and authentication.
\end{abstract}

Key words: Pharmacogenestic study, Amarogentin, HPLC, Swertia chirayita

\section{INTRODUCTION}

Plants have been used from ancient time for the curing of a variety of diseases and the efficiency of these drugs mainly depends upon the appropriate use and sustained availability of the valid raw materials [1].Those plants that contains active constituents which could be used for remedial purposes or for the synthesis of useful drugs are called medicinal plants [2].

The genuineness of the plant material plays a significant role for detection of standard plant material and comparison of adulterants. The Pharmacognostic study deals the structural, physical, chemical and sensory characters of the plant-drug which includes the history, botanical identification, collection, preparation and standardized of the plant to estimate the chief active constituent.

The total ash value reflects the Carbonate, Phosphate, Oxides, Silicate, and Silica, Which represents the purity index of medicinal plants. The acid-insoluble ash value represents the amount of silica and the water soluble ash is the water soluble portion of the total ash in the plant [3].

The Swertia chirayita an important species of Gentianaceae family. Floristic Swertia chirayita is a robust plant 60 to 180 centimeters in length, branching, teret except near top, stout, branching towards top, stem round ; quadrangular towards top, green. Leaves 70-90 X 35-40 mm broadly lanceolate, sessile, elliptic acute, 5- 7- nerved. Flowers tetramerous, calyx smaller than corolla, oblong, tip acute, green, 1- nerved, 5-6 $\mathrm{mm}$ in size.

Revised Manuscript Received on April 25, 2019.

Neetu Sharma, Department of Chemistry, Graphic Era Deemed to be University, Dehradun, India

Ashish Sharma, Department of Chemistry, Govt. Degree college, Raipur Dehradun, India

Kumud Pant and Department of Biotechnology, Graphic Era Deemed to be University, Dehradun, India.

Kapil Ghai, Department of Chemistry, Graphic Era Hill University, Dehradun, India.
Corolla is gamopetalous, greenish petals which are violet in centre. Bear two glands on each petal- each gland is a depression, which is bright green inside. Margin of the depression is covered by long purple hair which converges to form a summit. Its Androecium has 4- versatile filaments and anthers purple in colour, filament base slightly dilated. The tap root has yellowish pith with no smell. Fruit is a capsule bearing numerous minute seeds. The plant mostly grows in open, moist places and forest openings [4].

The ethno botanical utilization of this species is well known, it is used in its crude form for treatment against fever, treatment against scorpion sting, as a tonic for liver and heart. Its utility as an antidiabetic agent has also been recognized. In Ayurveda an infusion of the Swertia chirayita is generally employed for stomachic, febrifuge and anthelmintic treatment.

The wide spread use of Swertia chirayita in traditional medicine reflects its pharmacological importance for ages. Its antithelmintic, hypoglycemic and antipyretic properties are attributed due to amarogentin, swerchirin, swertiamerin and other active principles of the herb. The plant has been classed in critical endangered because existing populations of Swertia chirayita are diminishing due to various biotic factors[4].

During the preliminary surveys of the Swertia chirayita from the known site, it was found that most of the sites had very poor or non significant population to become representative site of Swertia chirayita expect for two sites, where the population of Swertia chirayita were significant and possessed good vigor.

\section{MATERIALS AND METHOD}

\subsection{Collection Of Plant Material:}

The plant specimen of Swertia chirayita were collected in the end of September from two different locations, the first being from the Kauntalani Nursery, Chakrata Forest Division, District Dehra Dun, Uttarakhand and the second site for the collection of plant material is Kaddukhal of Saklana Forest range in Narendranagar Forest Division.

\subsection{Identification Of The Plant Material}

The plant species has been confirmed and identified as Swertia chirayita by the plant taxonomist of Department of Botany, Forest Research Institute, Dehradun. and accession number $\underline{16430}$ has been assigned.

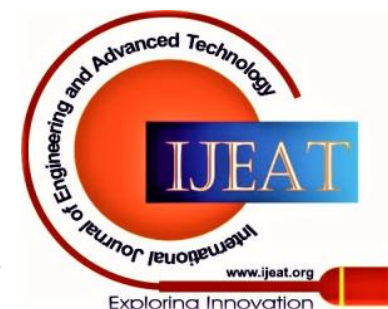




\subsection{Chemicals REquired}

Hydrochloric acid $(\mathrm{HCl})$, Silver Nitrate $\left(\mathrm{AgNO}_{3}\right)$ and Methanol $\left(\mathrm{CH}_{3} \mathrm{OH}\right)$ (Renkem Fine Chemicals Limited, Okhla, Delhi).
Take $2 \mathrm{~g}$ accurately weighed coarse dried powdered sample in a pre weighed petri dish and drying it in oven at $105^{\circ} \mathrm{C}$ till constant weight was achieved and was calculated as follows $[5]$.

\subsubsection{Moisture content (\%)}

$$
\text { Moisture content }\left(\% \frac{w}{w}\right)=\frac{\text { weight of oven dried drug sample }}{\text { weight of dry drug sample }} \times 100
$$

\subsubsection{Total ash (\%)}

$2 \mathrm{~g}$ accurately weighed drug sample (coarse powder) was heated upto $450^{\circ} \mathrm{C}$ in an electrical muffle furnace until the burnt ash become free from carbon, then cooled and weighed[5].

$$
\text { Total Ash }\left(\% \frac{w}{w}\right)=\frac{\text { weight of total ash }}{\text { weight of dry drug sample }} \times 100
$$

\subsubsection{Acid Insoluble ash (\%)}

The ash obtained after incineration was treated with 6 Normal $\mathrm{HCl}$ and the solution was boiled for 5 minutes and filtered. The residue was washed intermittently with distilled water. The filtrate was tested with Silver Nitrate $\left(\mathrm{AgNO}_{3}\right)$ to check Chloride ion for absence or presence. The residue left in the filter paper (ash less) was again incinerated and was completely converted to ash. After cooling, the weight of ash was noted and the acid-insoluble ash obtained was calculated by the formula given below [5].

$$
\text { Acid insoluble Ash }\left(\% \frac{w}{w}\right)=\frac{\text { weight of Acid insoluble ash }}{\text { weight of total ash }} \times 100
$$

\subsubsection{Water soluble ash (\%)}

ignited in a crucible for 15 minutes. After cooling, the weight of insoluble matter was subtracted from the weight The ash obtained after incineration was boiled in $25 \mathrm{ml}$ of water for 5 minutes and the insoluble matter was collected on an ashless filter paper. It was washed with hot water and of total ash and the percentage of water soluble ash obtained was considered as under[5]:

$$
\text { Water soluble ash }\left(\% \frac{w}{w}\right)=\frac{\text { weight of water soluble ash }}{\text { weight of total ash }} \times 100
$$

\subsubsection{Water soluble extractive (\%)}

Stirred $5 \mathrm{~g}$ accurately weighed powder in a $100 \mathrm{ml}$ distilled water in a conical flask and kept overnight. It was then filtered and the filtrate was evaporated on a water bath in a pre weighed, dried, evaporating dish. The evaporated filtrate was then dried to a constant weight in an oven. The water soluble extractive percentage was calculated using following formula[5].

$$
\text { Water soluble extractive }\left(\% \frac{w}{w}\right)=\frac{\text { weight of water soluble extract }}{\text { weight of dry drug sample }} \times 100
$$

\subsubsection{Alcohol soluble extractive (\%)}

Stirred $5 \mathrm{~g}$ accurately weighed sample powder and $100 \mathrm{ml}$ methanol in a conical flask, and kept overnight and after filtration the filtrate was evaporated on water bath in, a dried, pre-weighed a clean and porcelain evaporating dish.
After evaporation of the solvent, the evaporating dish was transferred to an oven for drying to obtain a constant weight of a residue, which was determined by using following formula [5].

$$
\text { Alcohol soluble extractive }\left(\% \frac{w}{w}\right)=\frac{\text { weight of alcohol soluble extract }}{\text { weight of dry drug sample }} \times 100
$$

\subsubsection{Determination of $p H$}

$5 \mathrm{~g}$ accurately weighed drug sample dissolved in $50 \mathrm{ml}$ distilled water was kept for about 30 minutes. It was filtered and $\mathrm{pH}$ was noted by digital $\mathrm{pH}$ meter[5] (Systronics Inc.).

\subsection{Method for quantification of amarogentin}

\subsubsection{Standard Solution}

In methanol a stock solution of Amarogentin $(1.6 \mathrm{mg} / 10 \mathrm{ml})$ was prepared. The aliquots of $0.5,1.0,1.5,2.0$ and $2.5 \mathrm{ml}$ of stock solution were transferred to $10 \mathrm{ml}$ volumetric flasks and the volume in each flask was adjusted to $10 \mathrm{ml}$ with mobile phase to obtain working standard solutions containing $0.5,1.0,1.5,2.0,2.5 \mathrm{mg}$ of amarogentin per $\mathrm{ml}$, respectively[6]

\subsubsection{Test Solution}

Refluxed $5 \mathrm{~g}$ of dried powdered of each sample with $50 \mathrm{ml}$ methanol for 4 hours. It was filtered and concentrated to dryness using Rota vapor and transferred to a separating funnel by adding $50 \mathrm{ml}$ of distilled water to this solution. After this, it was partitioned with $3 \times 50 \mathrm{ml}$ of Chloroform and then Chloroform layer was discarded.

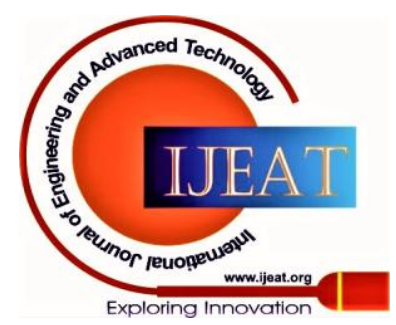


Similarly it was partitioned with overnight saturated Butanol $(3 \mathrm{X} 50 \mathrm{ml})$. The Butanol washings were pooled and concentrated. It was reconstituted with $10 \mathrm{ml}$ methanol and $10 \mu \mathrm{l}$ of this solution was injected to the HPLC system for analysis[6].

\subsubsection{Mobile Phase}

Methanol containing $5 \%$ water, filtered through $0.45 \mu \mathrm{m}$ membrane filter, degassed

By sonication at a flow rate of $1 \mathrm{ml} / \mathrm{min}$ was used in the present analysis.

\subsubsection{Detector}

All the samples were run for 20 minutes and components of the mixture were detected at $235 \mathrm{~nm}$ using Photodiode Array Detector (PAD) 2996 was used in the analysis.

\section{RESULTS AND DISCUSSION}

The outcomes of the proximate analysis of Swertia chirayita are shown in Table 1. The general moisture level in site KK was more than the site CK. For storage of drugs the moisture content needs be minimized to control the growth of bacteria, yeast or fungi [7]. Our findings indicated that, moisture content of the specimen was found to be $9 \%$ and $10 \%$ for the two samples of CK and KK respectively.

Table 1: Physico-Chemical Analysis Of Swertia Chirayita

\begin{tabular}{|l|r|r|}
\hline Parameter & CK & KK \\
\hline Moisture content (\%) & $9 \%$ & $10 \%$ \\
\hline Total ash (\%) & $4.75 \%$ & $\mathbf{4 . 7 0 \%}$ \\
\hline Acid Insoluble ash(\%) & $\mathbf{0 . 8 9 5 \%}$ & $\mathbf{0 . 8 1 1 \%}$ \\
\hline Water soluble ash (\%) & $\mathbf{2 . 1 6 5 \%}$ & $\mathbf{2 . 1 3 2}$ \\
\hline Water soluble extractive(\%) & $12.15 \%$ & $\mathbf{1 1 . 6 1 \%}$ \\
\hline Alcohol soluble extractive(\%) & $11.05 \%$ & $\mathbf{1 1 . 2 3 \%}$ \\
\hline pH & 7.1 & $\mathbf{6 . 8 5}$ \\
\hline
\end{tabular}

The results of comparative quantitative analysis of amarogentin in Swertia chirayita of two different sites are differences in different populations coupled with edaphic, climatic factors. depicted in Table 2

Result indicates that $\mathrm{CK}$ site has higher percentage of amarogentin than KK site, which may be due to genetic

Table 2: Comparative Analysis Of Amarogentin (\%) In Swertia Chirayita

\begin{tabular}{|l|l|l|c|}
\hline \multirow{2}{*}{ Population } & \multicolumn{3}{|c|}{ Amarogentin\% } \\
\cline { 2 - 4 } & Wild & Cultivated & Percent difference \\
\hline CK & $\mathbf{0 . 0 9 4} \pm \mathbf{0 . 0 0 3}$ & $\mathbf{0 . 0 9 3} \pm \mathbf{0 . 0 0 1}$ & $\mathbf{2 . 4 6}$ \\
\hline KK & $\mathbf{0 . 1 2 2} \pm \mathbf{0 . 0 0 2}$ & $\mathbf{0 . 1 1 9} \pm \mathbf{0 . 0 0 1}$ & $\mathbf{1 . 0 6}$ \\
\hline
\end{tabular}

The amarogentin quantity at both the site CK and KK was found to be .094 and 0.122 respectively. Though the amarogentin content is less than the expected level, it may be attributed to the environmental, edaphic factors, change in the use pattern of land, forest management practices. The ash content reported is not more than $6 \%$ [8] as the results of the present investigation indicated the ash content $4.75 \%$ and $4.70 \%$ respectively in the samples under investigation, which is well within the limit and the results are upheld by the previous investigations. So the material can be recommended for use as medicine and generally the whole plant is used as medicinal component. The percentage yield of all extractive are well within the limit as mentioned in Ayurveda Pharmacopoeia [8].

\section{CONCULSION}

The information regarding the chemical constituents present in the raw plant obtained from extractive values and also inform the solubility of specific constituents in particular solvents. The demand for genuine Swertia chirayita drug material is increasing with its potential use against diseases like Dengue, Chicken guinea, but the major natural quantities are insignificant as compared to the demand.

\section{REFRENCES}

1. Anon, "Role of state Forest development corporation", Proc. NMBP (National Medicinal Plant Board), 2007.

2. R. N. Okigbo , C. L. Anuagasi and J. E. Amadi "Advances in selected medicinal and aromatic plants indigenous to Africa" Journal of Medicinal Plants Research Vol. 3(2), pp. 086-095, 2009

3. J.Nisha , N. Anbu , P. Parthibhan and K. Kanakavalli "Systematic Standardization and Physiochemical Evaluation Of Novel Siddha Formulation Pungampoo Chooranam As Per Ayush Guidelines By Modern Analytical Techniques" International Journal of Medical Research and Pharmaceutical Sciences Vol. 4 (10), pp.55-64,2017

4. J. A. Duke, In Handbook of Medicinal Herbs, $2^{\text {nd }}$ Ed., CRC Press, Washington DC, pp. 190, 2002

5. Ayurveda Formulary of India (2000) Ministry of Health of Family Welfare. Govt of India

6. M. J. Kaur, "Phytochemical and antihepatotoxic investigations on "Chirata"-A traditional drug of Indian origin", Ph.D. Thesis, Punjab University, Chandigarh, India, 1994.

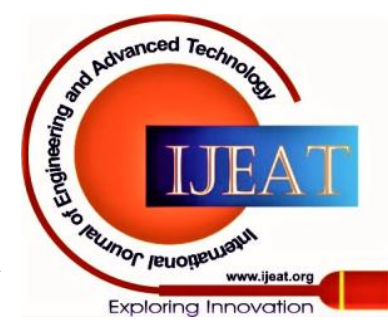


Pharmacognostic Study and Quantifiction of Active Component (Amarogentin) Of Swertia Chirayita by HPLC

7. A. Bhavik, U. Paresh, K. Rakesh K, "Evaluation of preliminary phytochemical and physicochemical studies on the seeds of Tectonagrandis Linn" , IJPI's J. of Pharmacognosy and Herbal Formulations, vol. 1, no. 3, pp. 25-29, 2011.

8. Anonymous, "The Ayurvedic Pharmacopoeia of India"Part I, vol $2,1^{\text {st }}$ Edn., Govt. of India, Ministry of Health \&Family Welfare, Department of ISM \& H, Delhi, The Controller of Publications, 1999. 